\title{
The Importance of The Leadership's Role in Education is Approaching the Era of Society 5.0
}

\author{
Weindiani* \\ Educational Administration \\ Universitas Pendidikan Indonesia \\ Bandung, Indonesia \\ *aniweindi@gmail.com
}

\begin{abstract}
Developing the revolutionary 4.0 industry in the field of information technology in the human order of life would further bring this order not only to a condition of $\mathbf{4 . 0}$ but more to society 5.0. the first four competencies, preparing a leader of strong character; both had the ability to speak a foreign language especially English; third, having the ability of the technology; fourth, the ability to write for the proposed ideas and new innovation thinking that can be transmitted to society 5.0 . research methods were done with the study of literature. Results and discussions of this article found that (1) among the innovative leadership styles needed in the society 5.0 era transformational leadership, participative leadership, and leader member exchange (LMX). (2) innovation in education becomes an innovative leader in the development of the society 5.0 in producing educators who could become character leaders and innovators. (3) strategies in creating innovation in education include, facilitative strategies, educational strategies, persuasion strategies, coercive strategies.
\end{abstract}

Keywords-era society 5.0, leadership, educational innovation, the educational innovation strategy

\section{PRELIMINARY}

A leader has a role that will determine the growth and sustainability of an organization that will have a view to the future. Innovation in an institution or organization will stop because it has organizational leaders who are easily satisfied with what they have achieved, do not have the enthusiasm and intention to improve organizational performance through continuous innovation.

The leadership style applied in an organization determines whether the organization will produce many innovations [1]. Basically, innovation is largely determined by the ability of organizational leaders to motivate employees so that they are willing to unleash their full potential. According to de Jong and Hartog in Djamaludin's book, it shows that there are three leadership styles that influence company or organizational innovation, including transformational leadership, participative leadership, and leader-member Exchange (LMX) [1].

At this time, we are in the era of the 4.0 industrial revolution where in this era the development of technology has been so rapid that it has changed many of the old orders that have been formed, the presence of this era opens new views about the importance of collaboration to solve complex problems. With the development of the era of the industrial revolution 4.0 in the field of information technology in the order of human life, it will increasingly bring this life order not only to conditions 4.0 but more advanced to society 5.0 .

With an innovative leader who will be ready to face the development of information technology that has been so rapid and increasingly sophisticated, has entered various aspects of life, including the world of education, thus requiring individuals to explore their potential. So that innovative leaders can create creative learning innovations that can welcome the era of society 5.0. The era of society 5.0 is marked by the development of digitalization not only in the industrial sector, but also in all aspects of human life. In the era of society 5.0, there are 4 competencies based on the first kompas.com article [2], preparing a leader with strong character; second has the ability to speak foreign languages, especially English; third, have IT technology capabilities; fourth, the ability to write to express ideas and ideas that are owned and new innovative thoughts that can be transmitted to society 5.0.

In welcoming this era of society 5.0, we aim to formgraduates with character and innovative leadership. Innovative leaders have a clear vision of the sustainability of their organization, and a leader is able to inspire his followers to share that vision and make it a reality. An innovative leader provides motivational support and resources for the creation of innovative products. Innovative ideas emerge from followers that must be appreciated and developed, then the leader prepares the necessary budget and facilities to turn innovative ideas into innovative products as well.

The role of leaders in innovation towards society 5.0 is focused on the styles and behavior of leaders who are able to stimulate the emergence of innovation and the characteristics and behavior of leaders become obstacles to innovation in an institution or organization.

Leaders will be successful in welcoming the era of society 5.0 by having the ability of a leader who can create a conducive 
work atmosphere so that it is meaningful to employees, the ability of leaders to treat each employee as part of a family whose contributions must be recognized, then leaders also need to develop employee competencies to be able to work professionally and innovatively.

With the development of technology in this era that will welcome the era of society 5.0, it will have an impact on the education system in Indonesia. The importance of the role of leaders in creating innovative educators has become the task of a leader as stated by Asep in Udin educational leadership is the ability to drive the implementation of education, so that the educational goals that have been set can be achieved effectively and efficiently [3].

So by taking the position of leader, it has the role of the task of creating educators with character and innovation, it is demanded to be leaders who have good body, spirit and morality, even proper socio-economic requirements. Likewise, a leader must have a good personality because the leader becomes a role model who will be followed by his followers.

Then what kind of leaders are needed in facing this era of society 5.0 in the world of education that can produce educators with character and innovators?

\section{DISCUSSION}

The development of the industrial revolution 4.0 in artificial intelligence, robotic, internet of things, biotechnology will increasingly bring this life order not only to its current state but more advanced to society 5.0 which is marked by digitization that is not only in the industrial sector, but enters all aspects of human life, likewise in the world of education. So, in welcoming this era, a leader with character and innovation is needed, so that it is the duty of a leader in creating an innovative world of education in order to create educators who will become leaders of the nation with character and innovators.

\section{A. Innovative Leadership Style}

When an organization or agency deteriorates, a leader is needed who's able to improve and save it. In this step the leader must take concrete steps to improve performance in the organization. So usually what is done by a transactional leader, they will dismiss or move their members who are not in accordance with the agreed course of the organization. However, if this is the case, then a leader only expects good results and does not pay attention to the performance of a member himself. So, in the book Djamaludin there are several leadership styles related to innovation, namely transformational leadership, participating leadership, and leader-member exchange (LMX) [1].

According to the view of Hickman, leadership styles in organizations can be divided into two forms, namely managers and leaders [4]. That is where both have differences in function, behavior, interests, see a power, and differ in its mindset.
The function of a manager is to closely supervise the work of his subordinates so that the work is carried out in accordance with the expected work systems, procedures and standards [1]. Managers do not care about changes that occur in the work environment they carry and work according to established procedures. Managers only focus on the internal conditions of the organization and solve short-term problems rather than thinking about the future. A leader sees himself as the holder of power.

On the other hand, according to Djamaludin the function of leader-style leadership is more farsighted and long-term planning [1]. And this leader-style leadership always wants to work and do something that is more than the expectations set, and he will look for breakthroughs to make new things exceed expectations. The interest of this leadership sees a regulation as a means of regulating freedom where the regulation is not a rigid one, and the rules that are made have a function to facilitate the implementation of organizational tasks can be achieved. A leader does not place his power into a high position but his expertise and intellect. The mindset possessed by the leadership of this leader emphasizes the intuitive aspect in dealing with his work and looks more at the progress that the organization will achieve.

So, it can be concluded what kind of leadership should be had in facing this era of society 5.0, namely leadership leaders who have the function and interest in building an organization to work together with the team in achieving mutually agreed organizational goals. This leadership is characterized by respecting humans as the most preferred resource in the progress of an organization or institution.

According to Yukl in Djamaludin, innovative leadership includes participatory leadership, Lmx, and transformational leadership [1]. Which is where this leadership has an influence on a person's leadership style in the innovation he will make. Participatory Leadership and its influence on Yukl's innovation in Djamaludin, states that this leadership has a type of decision making in an organization including [1]:

- Autocratic decision making, a leader who makes decisions without involving other people as subordinates.

- Consultation, a leader who asks for opinions and ideas from others.

- Making decisions together, leaders discuss with members in making a decision.

- Delegation, a leader who gives authority and responsibility to his subordinates to make decisions.

Participatory leadership is a leader who gives authority to its members to participate in making decisions and these decisions will influence the decisions made by the leader. This leadership has the greatest opportunity to develop the creativity of its members in producing innovative products. 
Leader-member exchange leadership has an influence on innovation. According to Hughes, this leadership emphasizes that leaders do not treat all their followers as a group of equals uniformly [5]. But in reality, the leader-forms specific and unique connections with each of his subordinates and forms several two-way relationships. The steps involved in making this two-way relationship include:

- Taking on the role, the leader offers the opportunity and evaluates the performance and potential and followers.

- Role creation, the stage of the trust building process.

- Routines, the phase when similarities and differences are reinforced.

This leadership emphasizes the reciprocal influence between the leader and its members due to the ongoing relationship within an organization. This relationship will affect the members' spirit of innovation, and the emergence of innovative work in the organization.

Transformational leadership and its influence on innovation, this leadership views members as people who are responsible, have an inner awareness to work, and are proud of their work [1]. This leadership has a humanizing nature follower, treats his followers as an intelligent and honorable man in order to bring the potential insaniyah-to fullest. Able to encourage members to develop aspirations and gain meaning in work, to be able to develop new leaders in their work environment, and to create an appreciative work environment so as to increase their enthusiasm for innovation and learning together, making themselves a model of integrity for their members.

According to Bass in Djamaludin [1], there are four things that characterize transformational leaders, namely:

- The idealized influence, exemplary traits shown to followers and qualities admired by followers of the leader.

- Intellectual stimulation, the leader invites followers to always question the assumptions behind something, looking for new ways of doing things.

- Caring individually, leaders who pay attention to the needs of their members and help-members so that they can progress and develop in their life.

- Inspirational motivation, leaders who provide inspiration at work, invite employees to realize a common goal so that their lives and works become meaningful.

So, from some of the leadership styles that have been described, transformational leadership styles that deserve to be developed in the world of education where this leader has a human nature, where the leader really appreciates the performance of its members and works together as a team in developing an organization-or agency to be successful with the results of collaborative work. Good by having a good relationship between the leader and also its members. This leadership is needed in welcoming the era of society 5.0 which can create educators with character and innovators by imitating leaders who have a transformational style.

\section{B. Educational Innovation}

In the sense of leadership above, in creating educators with character, leader-style leadership and transformational leadership are needed. In order to create innovative education.

The rapid development of technology and information in various aspects of life, including education, is an effort to bridge the present and future by introducing reforms that tend to pursue efficiency and effectiveness.

Before heading into what innovation in education is, it is necessary to know what innovation means. Innovation according to Udin [6] means that innovation is an idea practical things, methods, methods, human-made things, which are observed or felt as something new to a person or group of people (society). This new thing can be in the form of an invention or a discount, which is used to achieve a certain goal or to solve a problem. So, in the sense that innovation itself must have a leader who can create something new, especially in the field of education so that his followers are ready to face this era-society 5.0

With the many challenges that a leader must face in preparing for the era of society 5.0 in the field of education, leaders are required to create new things, policies, and efforts to improve their abilities to achieve certain goals in education. As for some examples of educational innovations in each component of education or components of the social system according to what was stated by B. Miles in Udin's book [6], these changes are adapted to current developments including: personnel development, number of personnel and work areas, physical facilities, usage time, formulation of goals, procedures, roles required, insights and feelings, forms of relationships between parts (working mechanisms), relationships with other systems, and strategies to be carried out.

The emergence of this educational innovation is caused by challenges that need to be solved with new and progressive thinking. Where this innovation is a basic effort to improve aspects of education to make it more effective and efficient.

\section{Educational Innovation Strategy}

One of the factors in determining the effectiveness of implementing a social change program is the accuracy of using the right strategy, but choosing this strategy is certainly not easy. In determining this strategy, it must be observed where the weakest and strongest points of the strategy can be implemented. So Udin [6] formulates four kinds of educational innovation strategies, namely:

- Facilitative strategy, social change using this strategy to achieve the stated goals of social change, prioritizing 
the provision of facilities with the aim that the social change program will run easily and smoothly. However, facilities and facilities do not have much benefit to support change if teachers and education implementers as targets of change do not understand the educational problems they face. This strategy'll work well with the support of a good program.

- Educational strategy, making social changes by conveying facts with the intention that people will use the facts or information to determine the action to be taken.

- Persuasion strategies, by providing reasons, encouraging, or inviting to follow the examples given. Persuasion strategies can be successful based on rational reasons, providing accurate facts.

- Coercive strategy, by forcing to achieve change. The aspect to be enforced must be the form of the expected target results. The ability to implement coercion depends on the control relationship between implementing changes and targets.

Thus, the strategy that can be used by a leader in making an innovation must use the right strategy, including by using a strategy by giving him the means and facilities, and coercion. If the implementation of this change program understands a variety of strategies, it must be prioritized to achieve certain change goals, although it can be combined between the strategies used in creating a change.

\section{RESEARCH METHODS}

This study uses a methodology in accordance with what will be discussed, which includes the types of research methods, data collection techniques, and also has problem boundaries which will be explained as follows:

\section{A. Types of Research}

The type of research used in this research is descriptive research. Descriptive research method is a type of research that aims to describe in detail the phenomena that occur. So, in this case the researcher wants to observe or research about what is the importance of the role of innovative leaders in the world of education towards the era of society 5.0 ?

\section{B. Data Collection Technique}

Based on this research, the writer used literature study. In this technique the authors collect data and explore data in accordance with the discussion of the importance of the role of innovative leaders in the world of education towards the era of society 5.0. in this case the data obtained from various books and literature, journals, articles and information from print and electronic media that are relevant to the problem being observed.

\section{CONCLUSION}

Based on the results of the discussion that has been stated above, several conclusions can be drawn, namely:

- An innovative leadership style that can produce character, innovative educators and become leaders who can be role models. Leadership can be a role model by looking at the leadership style it uses, such as the leadership style of a manager or leader. There are three innovative leadership styles including: participatory leadership, leader-member exchange, and transactional leadership.

- Educational innovation that must be created by a leader in welcoming the era of society 5.0 by marking the digitalization which has become the order of human life in this era and has developed in the world of education. So transformational leaders should be able to produce innovations in the field of education, which is closely related to the quality of a country's human resources. The emergence of this educational innovation is caused by challenges that need to be solved with new and progressive thinking. Where this innovation is a basic effort to improve aspects of education to make it more effective and efficient.

- What strategies will be carried out in creating educational innovations that will be made by a leader include: facilitative strategies, educational strategies, persuasion strategies, coercion strategies. This strategy can be combined among one another and thus creating a change in social effectiveness and conduciveness.

\section{REFERENCES}

[1] A, Djamaludin, Psikologi Kepemimpinan \& Inovasi. Jakarta: Erlangga, 2012

[2] Kompas, "4 kompetensi lulusan ini jadi kunci "society 5.0"," 2019 [Online]. $\quad$ Retrieved from: https://edukasi.kompas.com/read/2019/03/20/21391851/4-kompetensilulusan-ini-jadi-kunci-society-50?page=all (3 December 2019, 10.00)

[3] S. Udin, Bunga rampai administrasi pendidikan teori dan praktik. Bandung: Alfabeta, 2019.

[4] C.R. Hickman, Mind of a Manager Soul of a Leader. New York, NY: Wiley, 1990.

[5] R.L. Hughes, R.C. Ginnett, and G.J. Curphy, Leadership: Memperkaya pelajaran dari pengalaman. Edisi Ketujuh, Jakarta: Salemba Humanika, 2012).

[6] S. Udin, Inovasi pendidikan. Bandung: Alfabeta, 2010 